\title{
Supporting development of community-based tourism: A perspective from "Sewu Kembang" Nglurah tourism village in Karanganyar regency
}

\author{
${ }^{1}$ Henny Kustini, ${ }^{1}$ Ratna Susanti* \\ ${ }^{1}$ Diploma of Hospitality, Polytechnic of Indonusa Surakarta, Indonesia \\ *Corresponding author: \\ ratnasusanti19@poltekindonusa.ac.id

$\begin{array}{llll}\text { Received: } & \text { Revised: } & \text { Accepted: } & \text { Published: } \\ \text { 11 June 2020 } & \text { 30 July 2020 } & \text { 31 July 2020 } & \text { 31 July 2020 }\end{array}$

\begin{abstract}
In Nglurah tourism village, it can be found some attractions that have the potential to develop. Some attractions have been developed by involving the community in its management, but its development has not been as expected. The purpose of this research is to know the attitude of the community and the level of human resources of the community of Nglurah tourism village in supporting the development of community-based tourism and the right strategy for its development. The CBT concept (Community-Based Tourism) that is applied to achieve sustainable tourism management was applied in the forms of local community participation, tourism village institute creation, environmental-based tourism attractions management, and the creation of small business activities by the locals. This research uses a qualitative approach with a descriptive type of research. The data resource of this research was in the forms of primary and secondary data with a data collection that was done through observation, interviews, documentation, and FGD (Focus Group Discussion). The data analysis uses stages, which are data collection, data condensation, data presentation, and conclusion drawing. The result of this research shows that the management of tourist attraction in "Sewu Kembang" Nglurah Tourism Village appears from the initiative of the local's people, the locals have agreed on the creation of tourism village institute, the creation of Pleseran Campsite, Dukutan ceremonies, Embankment site management priority programs as the main attraction and the emergence of community business activities as a result of the tourism attraction management.
\end{abstract}

Keywords: tourism village; community participation; community-based tourism (CBT)

\section{INTRODUCTION}

Rural tourism or tourism in rural areas is a new form of activity that can bring economic and social benefits to society. It will not only generate employment for the people, but it can also develop social, cultural, and educational values; therefore, rural tourism has attracted increasing attention from governments, NGOs, and other organizations (Ghaderi \& Henderson, 2012; Ghasemi \& Hamzah, 2014). 
Kustini, H., \& Susanti, R. (2020). Supporting development of community-based tourism: A perspective from "Sewu Kembang" Nglurah tourism village in Karanganyar regency. Journal of Advanced Multidisciplinary Research, 1 (1), 22-31. DOI: http://dx.doi.org/10.30659/JAMR.1.1.22-31

Tourism village is one representation of Community-based Tourism development. In order to achieve the efficiency and effectiveness of productive programs in Sustainable Tourism-based Community Empowerment, it is necessary to do tourism activities in rural areas by developing rural tourism as a program that is able to accelerate economic, social, cultural, and environmental growth in accelerating growth in rural areas (Bălan \& Burghelea, 2015). The program is accelerating the development of tourism villages is one of the activities carried out by the government to achieve the realization of 2000 tourist villages. Village tourism is a form of integration between attractions, accommodation, and supporting facilities that are presented in a structure of community life that integrates with applicable procedures and traditions (Xue et al., 2017).

One representation of Community-based Tourism development is the Tourism Village where the concept of tourism development is still a hot topic of discussion in the media, as well as the themes of Research and Community Service, both among nongovernmental organizations and universities. As one of the synergies of government programs in this case, the Ministry of Tourism, which is associated with the role of universities in community empowerment programs (Priyanto, 2016).

Sustainable tourism in a rural setting is the subject of a growing literature, reflecting interest amongst academics and industry practitioners from both public and private sectors (Ghaderi \& Henderson, 2012). ThereThe object of this research is the village of Nglurah Karanganyar District which has its own characteristics and has considerable economic potential. The goal achieved is to find out the tourism potentials in Nglurah and how to develop Nglurah as Sewu Kembang Tourism Village. The target to be achieved from this program is that partners can have knowledge and insight as village people who have awareness about the potential of their area and in their businesses ornamental plants and can develop their business from the improvement of their soft capacity. With the development of this business will have a positive impact that is increasing the economic partner, providing comfort in society.

The purpose and purpose of assistance are to accelerate empowerment, which is to develop strength or ability (power), potential, human resources that exist in human beings to be able to develop themselves. In assistance, activities need to have clear goals and objectives and can be seen from the results. The formulation of the problem in the research is to find out the tourism potentials in Nglurah and how to develop Nglurah as a Tourism Village.

The village has potential as a community-based tourist destination and is based on the wisdom of the local cultural community and can also be a trigger for economic improvement based on mutual cooperation and sustainability (Sutedjo et al., 2018). This is in accordance with the principle of building from the periphery or from the village for the welfare of the Indonesian people by exploring the local potential and community empowerment that was declared by the government as a priority program.

The purpose of assistance is to accelerate empowerment, which is to develop strengths or abilities (potentials), potentials, human resources available in human beings 
to be able to develop themselves. In assistance, activities need to have clear goals and objectives and can be seen from the results.

Nglurah Karanganyar village community, as a target in this program, has its characteristics and has considerable economic potential. By doing this village tourism assistance program, its characteristic capital and considerable economic potential of the Nglurah Village can accelerate empowerment, which is to develop strengths or abilities, potentials, human resources available in the Nglurah village to be able to create themselves. Base on the CBT program in "Kembang Sewu" Nglurah tourism village in Karanganyar, this paper aims to involve community members in decision-making, the local communities' benefit from tourism activities, and education of tourism for local communities."

Community-based development is an umbrella term for projects that actively include beneficiaries in their design and management, and community-driven development refers to community-based development projects in which communities have direct control over key project-decisions, including management of investment funds. Weaver observed that community-based tourism (CBT) was referred to in the early 1980 s as the sine qua non of alternative tourism. Hopes were especially high of combatting mass tourism in the developing world and aiding rural communities in the global south through grassroots development, resident participation, empowerment and capacity building (Weaver, 2010).

Community-based tourism (CBT) is increasingly considered as a more sustainable alternative, as it emphasizes the active involvement of the local community as catalyst in the tourism development (Marinovski, 2016). CBT is a concept of developing a tourist destination through empowering local communities, whereby the community contributes to planning, managing and delivering opinions. Community-Based Tourism (CBT) is tourism that takes into account environmental, social and cultural sustainability aspects and is a tool for community development and environmental conservation or in other words CBT is a tool for sustainable tourism development (Utami et al., 2019). CBT has been applied in developed member economies, such as Canada, New Zealand and Australia, as well as in developing economies like Vietnam, Indonesia, China, and Malaysia. Many of the CBT issues stem from internal problems such as weak business models that cannot support CBT activities. The economic fragility of CBT has prompted researchers to argue that, if CBT is to be profit-oriented, then it should be run as a business entity. This calls for a sophisticated approach to ensure its economic sustainability (Churyen et al., 2015). The representation of the development of Community-based Tourism is a Tourism Village, program that was rolled out by the government in rural tourism activities by developing tourist villages as a program able to accelerate economic, social, cultural and environmental growth in rural areas.

Community-based tourism is increasingly seen as a more sustainable alternative, because it emphasizes the active involvement of local communities and their control over tourism development. Community-based tourism (CBT) is increasingly considered as a more sustainable alternative, as it emphasizes the active involvement of the local community and their control of the tourism development (Marinovski, 2016). The concept of community-based tourism or Community Based Tourism, abbreviated as 
Kustini, H., \& Susanti, R. (2020). Supporting development of community-based tourism: A perspective from "Sewu Kembang" Nglurah tourism village in Karanganyar regency. Journal of Advanced Multidisciplinary Research, 1 (1), 22-31. DOI: http://dx.doi.org/10.30659/JAMR.1.1.22-31

CBT, is a concept of developing a tourist destination through the empowerment of local communities. Where people take part in planning, managing and delivering opinions. Community Based Tourism (CBT) is tourism that takes into account aspects of environmental, social and cultural sustainability. CBT is a tool for community development and environmental conservation or in other words CBT is a tool for sustainable tourism development.

Community-based tourism is meant for disadvantaged community members and can be related to issues such as empowerment, sustainability, social justice and selfreliance. Nevertheless, even though the meaning of CBT is debated and each definition has its own specifics, "there are recurrent elements in the conceptualisation of CBT; that is, sustainable community development should involve participatory management of the planning, implementation, and evaluation of tourism projects". CBT is a tourism that is planned, developed, owned and managed by the community for the community, guided by collective decisionmaking, responsibility, access, ownership and benefits (Giampiccoli \& Saayman, 2018).

The tourism village acceleration program is able to reduce the urbanization (displacement) of rural people to the city, and trigger villagers to develop their villages in making tourism products such as making their villages as tourist villages that can provide employment opportunities so that people will not look for work to the city (Gao $\& \mathrm{Wu}, 2017)$. The village as a tourist destination requires management and improvement of facilities and infrastructure needs while the Human Resources in the village still have limitations in terms of management and knowledge of their village in this case, assistance is needed to make the village a tourist village. Village facilitation is one of the strengths that will greatly help villages accelerate their steps to become empowered villages. It's just that the work of assistance is not haphazard work.

\section{METHOD}

The research method used is descriptive qualitative data collection techniques. Descriptive qualitative method which focuses on case study was applied for analyzing the potential of the region as a tourism village. The formulation of the problem studied by researchers is: (1). the tourism potential of "Sewu Kembang" Nglurah, Tawangmangu, Karanganyar regency based on supporting and inhibitors factors and (2). community- based tourism development strategies in "Sewu Kembang" Nglurah, Tawangmangu, Karanganyar regency. The location of this study is the tourist village of "Sewu Kembang" Nglurah, Tawangmangu, Karanganyar Regency.

Data were collected using two techniques, which are: (a) primary data collection through field observations and interviewing the local community, (b) secondary data collection through literature studies and institutional survey. Data collections were made for the involvement of community in tourism activities, the benefits of tourism village development to the residential neighborhood, and the opportunity for citizens to obtain fixed income. 


\section{RESULT AND DISCUSSION}

\section{Result}

Community-based tourism is a form of tourism in which the local community has control and is involved in its development and management, and a large proportion of the benefits remain in the hands of the local community. The development of Nglurah Tourism Village are: (1) Creating an integrated tour package and preparing homestays that are in accordance with standards, tourist attractions and other things that support the development of tourism villages; (2) Increase knowledge about homestay management; (3) Build management structures of Tourism Awareness Groups (on Bahasa: Pokdarwis) so that it becomes more efficient and effective; (4) Increase the optimization of bamboo-based products that have competitive advantages; (5) Building a community mindset, that the existence of tourism villages can increase community income; (6) Increase the effectiveness and efficiency of technological resources to support various needs for developing rural tourism for example by optimizing social media such as Facebook, Instagram, YouTube and also websites; (7) Adding an element of education in tourist attractions so that tourists not only enjoy their natural beauty but also gain a new knowledge when visiting Nglurah Tourism Village, and (8) The government and academics should conduct sustainability training program in order to increase the competency of the local community.

\section{Discussion}

\section{Overview of "Sewu Kembang" Nglurah Tourism Village}

Nglurah tourism village is the District of Tawangmangu, Karanganyar Regency, The Central Java Province. The people of Nglurah tourism village have their own characteristics and have considerable economic potential. Nglurah tourism village itself has a community that is aware of the importance of preserving a culture and has a cultural group called Wagu Budoyo. What is interesting is that this group is mostly participated by young people. The youths from Nglurah touris village have an awareness that culture must be preserved.

Nglurah Village is still categorized as a pilot village so it still needs assistance from the Tourism Department. Under the assistance of the Tourism Department, a Tourism Awareness Group (Pokdarwis) has been established named "Sewu Kembang". The purpose of this Pokdarwis is to make people aware of the importance of community participation in building tourism villages. Community involvement in the village tourism assistance program is coordinated by the aforementioned communities. The establishment of Homestay, Culinary and Tourism Business groups (including local \& destination transportation) is managed by the existing community; namely POKDARWIS Sewu Kembang, Karang Taruna Gumbregah and Wagu Budoyo Cultural Studio. Most of the Nglurah villagers who are also members of the Sewu Kembang POKDARWIS consist of 2 RWs and have around 90 households. However, only around 25-30 people actively gathered, held activities and participated in training conducted by the Polytechnic Indonusa Surakarta student's. Likewise, Gumbregah Youth Organization and Wagu Bodoyo Cultural Studio, where most of the young members 
Kustini, H., \& Susanti, R. (2020). Supporting development of community-based tourism: A perspective from "Sewu Kembang" Nglurah tourism village in Karanganyar regency. Journal of Advanced Multidisciplinary Research, 1 (1), 22-31. DOI: http://dx.doi.org/10.30659/JAMR.1.1.22-31

conduct further studies or work outside the city. The livelihoods of the people who are mostly ornamental plant farmers as well as sellers and traders force them to spend some time to spend on other activities. Time constraints and priority scale become challenges for the team to coordinate and cooperate with existing community communities to conduct mentoring programs, ranging from socialization, direction, training, coaching to monitoring.

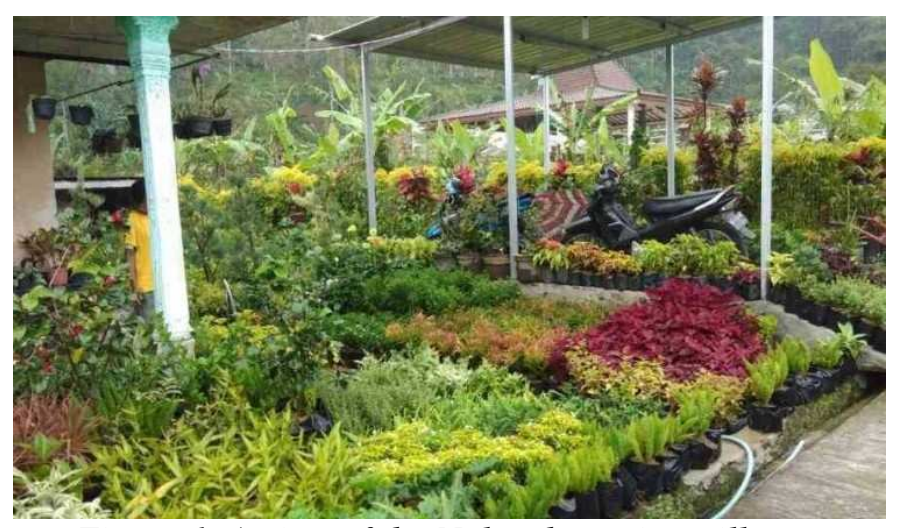

Figure 1. A view of the Nglurah tourism village

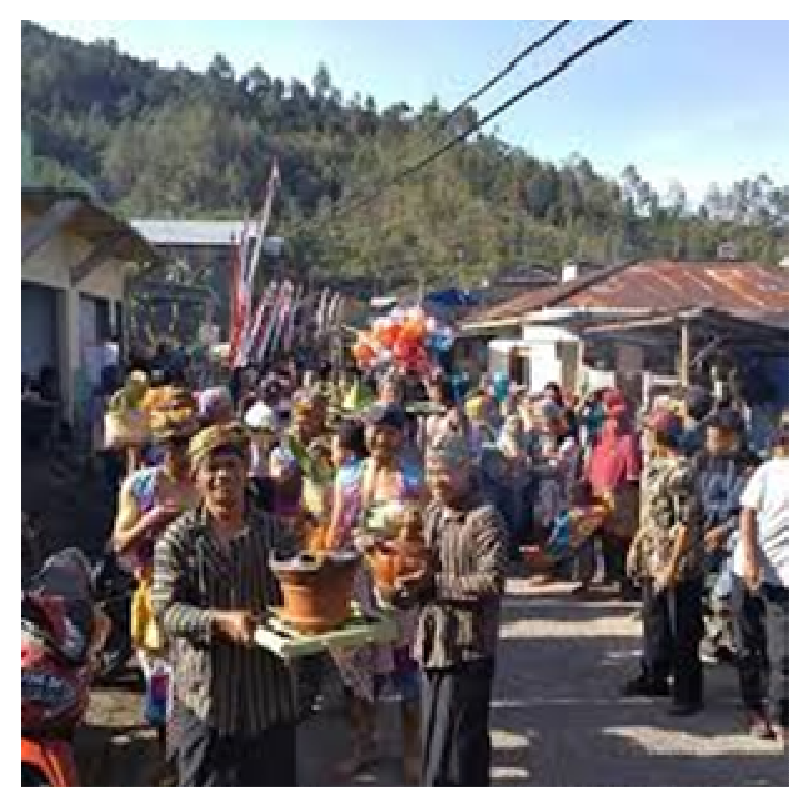

Figure 2. Dukutan ceremony

Source: https://www.krjogja.com/

POKDARWIS Sewu Kembang, as the name implies, is a form of expression of the majority of people whose livelihoods are ornamental plant farmers for generations, which in the end want other income to meet their needs. Tourism became an option with the issuance of a Decree of the Head of the Tourism Office on Tourism Villages in Karanganyar Regency which was in the process of becoming a Regent's Decree. 


\section{Identification of the Potential of Nglurah Village as a Tourism Village}

The aim of this research is that in the end the community can have knowledge and insight as a village community who has awareness about the potential of their area and in the business of ornamental plants and can develop their business from the improvement of their soft capacity. With the development of this business will have a positive impact that is increasing the economic partner, providing comfort in society.

Assistance methods are carried out starting from surveys and identification to community training using andragogy methods, supervision techniques, coaching, monitoring, evaluation and reporting.

A strong commitment from all components of the village needs to be maintained to equalize opinions, perceptions and raise the potential of the village to become a tourist village. This commitment is the strongest support for the realization and sustainability of the tourism village

Identification of the positive or negative impacts of a tourism activity according to the uniqueness of each village also needs to be done. Each village has its own characteristics will produce impacts that are also different from each other, especially socio-cultural changes. A strong commitment from all components of the village needs to be held in cooperation with the Regional Government and if necessary cooperating with the private sector. Thinking about and identifying impacts also if working with the private sector. This includes budgeting for the development of a tourist village using all available economic resources. In addition, it is also necessary to prepare all the rules / regulations norms that are more intended to oversee the development of tourist villages and oversee potential deviations that might occur. Regulations are prepared so that the running of tourist activities and their impacts remain in the corridor of regulation as the legal umbrella

Therefore, training for all components of the village, needs to be done including the village government on tourism management, how to manage tourist attractions, guest / visitor management, along with innovations that need to be developed considering that as other sectors the tourism sector also fluctuates and can experience " saturation".

The use of various media also needs to be done to introduce and publicize tourism potential in the village both conventional and unconventional media, such as the internet media. The internet has now become a very effective publication tool that can reach all parts of the world. Tourist sites whose locations are remote can also be known by people in other parts of the world thanks to internet technology. Equally important is learning about the success of other tourist villages or comparative studies. We can learn a lot on the success of other tourist villages, especially similar ones. Because typical problems and future challenges that will be faced are more or less the same. Only with professional and innovative management will the tourism village exist and be competitive and can pass internal, external and regional exams.

Reporting is a follow-up from factual supervision, which illustrates the overall content of the results of assistance, starting from the beginning to completion, so that it 
Kustini, H., \& Susanti, R. (2020). Supporting development of community-based tourism: A perspective from "Sewu Kembang" Nglurah tourism village in Karanganyar regency. Journal of Advanced Multidisciplinary Research, 1 (1), 22-31. DOI: http://dx.doi.org/10.30659/JAMR.1.1.22-31

shows the developments, problems, and solutions carried out in the mentoring-based tourism village development program.

Training has been given to the community and enthusiasm for learning and becoming better has also been seen in the majority of Nglurah villagers. The main livelihoods as farmers, sellers and traders are a challenge for the community to apply the material provided.

Quantitatively the number of community members actively involved in the community has increased. Curiosity and additional revenue from the tourism sector by using the existing potential made the community begin to carry out tourism activities through the rural tourism program. The number of POKDARWIS members who are mostly dominated by homestay management housewives has also increased. The potential for additional income is the main reason besides wanting to empower their homes where some of the rooms (bedrooms) are empty because some family members migrate out of town. Mothers who already have a home-based food stall and catering business are also enthusiastic about attending various kinds of training. New knowledge in the culinary field provided by the team of food production lecturers and supported by PCPI (Indonesian Professional Chef Association) BPC Solo Raya added to their insights on local food ingredients, processing to presentation, including packaging. Similarly, insights about making drinks from ingredients obtained from local. Tea is one of the characteristics of the Nglurah region. The tea mixology theory with a mixture of several other local ingredients was given as training material and was applied by the ladies when we came to do the monitoring activities.

Likewise with young people members accommodated by Youth Organization and Cultural Studio. The emergence of a sense of pride in their area and the confidence to tell what their villages have becomes the initial capital to be able to market and sell tourism potential that already exists. Awareness as a youth to build his village was seen during our next visit we did with agile and smoothly they took the team to do a mini tour to nearby tourist objects. The spirit of telling the history, the origin of the occurrence, and do's \& don'ts of a tourist attraction proves that the initial target of the results of the assistance program was successful. Neither did the formation of a local transportation service group that existed at the beginning of the team's arrival. They have coordinated with several parties to support the arrival of tourists in large groups / groups.

The hope of most of the village community is that this team continues to assist village tourism on a regular basis and does not stop here. They also expect the same support from the local, regional and central governments to continue to work together to support the acceleration of the tourism village program with the immediate issuance of a Regent's Decree which establishes Nglurah as a Tourism Village with the main potential, the Center for Ornamental Plants. Groups in society must be encouraged to grow and develop on the basis of their willingness and ability to learn to discover for themselves what they need and what they will develop, including efforts to change their livelihoods and lives. 
Motivation and training in tourism businesses make most young people aware of the enormous natural and cultural potential that their village has. The added insight about the processed food and drinks whose ingredients are taken from the local area made the housewives and catering caterers able to provide more services to visitors or tourists. Knowledge about food hygiene \& sanitation also adds their insight about the preparation and presentation of foods and drinks that are healthy and not harmful to the human body. Likewise for the homestay managers, initially only 4 houses have received tourist visits. With this training, the community realizes how the potential to provide lodging services can be realized by utilizing existing facilities that have not been utilized at all. Training on homestay business which includes homestay management from ordering, handling while staying to maintenance of facilities also makes mothers more motivated to prepare their homes as professionally managed homestays.

\section{CONCLUSION}

The implementation of the concept of the community-based tourism of Nglurah Tourism Village which is a pilot tourism village is included in the category of potential tourism villages whose people have high enthusiasm in managing the tourist attraction, even though there are still obstacles in its implementation. The concept of CBT that is applied to achieve sustainable tourism management is applied in the form of participation of local communities, the establishment of tourism village institutions, eco- friendly tourist destination and creative industry. The development of Nglurah as a Sewu Kembang Tourism Village is carried out through a mentoring program through community groups so that awareness of the potential of the region and the business of ornamental plants can develop their business from the improvement of their soft and hard capacity. Based on the results of this study it is suggested that there is a business or program that can facilitate a community service program for Nglurah as a Tourism Village.

\section{ACKNOWLEDGEMENTS}

We thank the Nglurah Village Committee and all the interviewees for their help and support, which make the research finished smoothly.

\section{REFERENCES}

Bălan, M., \& Burghelea, C. (2015). Rural Tourism and its Implication in the Development of the Fundata Village. Procedia - Social and Behavioral Sciences, $188(1360 \mathrm{~m}), 276-281$. https://doi.org/10.1016/j.sbspro.2015.03.393

Churyen, A., Duangsaeng, V., \& Kontogeorgopoulos, N. (2015). Homestay Tourism and the Commercialisation of the Rural Home in Thailand. Asia Pacific Journal of Tourism Research, 20(1), 29-50.

Gao, J., \& Wu, B. (2017). Revitalizing traditional villages through rural tourism: A case study of Yuanjia Village, Shaanxi Province, China. Tourism Management, 63, 223-233. https://doi.org/10.1016/j.tourman.2017.04.003 
Kustini, H., \& Susanti, R. (2020). Supporting development of community-based tourism: A perspective from "Sewu Kembang" Nglurah tourism village in Karanganyar regency. Journal of Advanced Multidisciplinary Research, 1 (1), 22-31. DOI: http://dx.doi.org/10.30659/JAMR.1.1.22-31

Ghaderi, Z., \& Henderson, J. C. (2012). Sustainable rural tourism in Iran: A perspective from Hawraman Village. Tourism Management Perspectives, 2-3, 47-54. https://doi.org/10.1016/j.tmp.2012.03.001

Ghasemi, M., \& Hamzah, A. (2014). An Investigation of the Appropriateness of Tourism Development Paradigms in Rural Areas from Main Tourism Stakeholders' Point of View. Procedia - Social and Behavioral Sciences, 144, 1524. https://doi.org/10.1016/j.sbspro.2014.07.269

Giampiccoli, A., \& Saayman, M. (2018). Community-based tourism development model and community participation. African Journal of Hospitality, Tourism and Leisure, 7(4), 1-27. http//: www.ajhtl.com

Priyanto, P. (2016). Pengembangan Potensi Desa Wisata Berbasis Budaya Tinjauan Terhadap Desa Wisata Di Jawa Tengah. Jurnal Vokasi Indonesia, 4(1). https://doi.org/10.7454/jvi.v4i1.53

Sutedjo, A., Prasetyo, K., \& Sudaryono, L. (2018). Condition of karangkepatihan village community balong district ponorogo regency in supporting development of community based tourism. Journal of Physics: Conference Series, 953(1). https://doi.org/10.1088/1742-6596/953/1/012175

Utami, M. M., Taufik, H., \& Bhakti, W. N. (2019). VILLAGE TOURISM : THE IMPLEMENTATION OF COMMUNITY-BASED TOURISM. International Conference of Organizational Innovation (ICOI 2019), 100(Icoi), 537-542.

Weaver, D. (2010). Community-based tourism as strategic dead-end. Tourism Recreation Research, 35(2), 206-208. https://doi.org/10.1080/02508281.2010.11081635

Xue, L., Kerstetter, D., \& Hunt, C. (2017). Tourism development and changing rural identity in China. Annals of Tourism Research, 66, 170-182. https://doi.org/10.1016/j.annals.2017.07.016 